\title{
TABLE OF TREATIES AND LEGISLATION
}

\section{TREATIES}

\section{Multilateral and bilateral treaties}

Accord général entre le gouvernement de la République française et le gouvernement de la République arabe unie, in: La documentation française, 18 October 1958, no. 2473; RGDIP, 1958 13.68

Agreement between Canada and the Czech

Republic for the Promotion and

Protection of Investments, signed on 6 May 2009, into force on 22 January 2012 $3.13,6.09$

Agreement between the Government of the

Russian Federation and the Cabinet of Ministers of the Ukraine on the Encouragement and Mutual Protection of Investments, 27 November 1998 6.154

Agreement between the Government of the

United Kingdom of Great Britain and Northern Ireland and the Government of the United Arab Republic

Concerning Financial and Commercial Relations and British Property in Egypt, in: UKTS 1959, no. 35 (Cmd. 723); 343 UNTS, p. 159; 14 Rev. égyptienne d.i., 1958 13.68

Agreement on Principles of Relations between Serbia and Montenegro within the Framework of a Union of States, signed in Belgrade on 14 March 2002 1.45

Agreement between the Russian Federation and the Republic of Crimea on the Accession of Republic of Crimea to the Russian Federation and on
Forming New Federal Constituent Entities within the Russian Federation, signed in Moscow on 18 March 2014, The Collection of Legislation of the Russian Federation, 7 April 2014, No. 14 6.106

Agreement Establishing the Commonwealth of Independent States, 13 December 1991, UN Doc. A/46/771, (1992) 31 ILM 138 $3.17,3.18,4.35$, 4.36, 7.07, 13.06

Convention (IV) relative to the Protection of Civilian Persons in Time of War, Geneva, 12 August 1949 .... 6.167, 7.07

Convention (IV) respecting the Laws and Customs of War on Land and its Annex: Regulations concerning the Laws and Customs of War on Land, The Hague, 18 October 1907 ..... 6.167

Convention on the Settlement of Investment Disputes between States and Nationals of Other States (Mar. 18, 1965) (entered into force Oct. 14, 1966), 575 UNTS 160; (1965) 4 ILM 532 $1.14,2.09,9.01,9.02$ 9.10, 15.02, 16.22 $16.23-16.26,17.01$

Declaration of Alma Ata, 21 December 1991, UN Doc. A/46/60, 30 December 1991, in (1992) 31 ILM ..... 1.37, 3.17, $3.18,4.35,4.36,4.37,7.07$

Draft Agreement on Transitional Measures, 2 Nov. 1949, (1950) 272

UNTS 13.86 
Joint Declaration of the Government of the People's Republic of China and The Government of the Republic of Portugal on the Question of Macao, China-Port., Apr. 13, 1987, 1498 UNTS 229 ........ 1.37, 6.46, 6.48, 6.56, $6.71,6.83,6.84,6.85,6.91,6.98$

Joint Declaration of the Government of the United Kingdom of Great Britain and Northern Ireland and the Government of the People's Republic of China on the Question of Hong Kong with Annexes, China-UK, Dec. 19, 1984, 26 UKTS (1985) $6.44,6.45$

Machakos Protocol, signed on 20 July 2002 14.39

Paris Peace Treaty, signed on 10 February 1947 at Paris, entered into force on 15 September 1947, in: 49 UNTS 126; UKTS 1948, no. 50 (Cmd. 7481) 13.26

Protocol Additional to the Geneva Conventions of 12 August 1949, and Relating to the Protection of Victims of International Armed Conflicts (Protocol I), 8 June 1977 6.167

Resolution of the Heads of the Commonwealth of Independent States on Succession to Treaties of Mutual Interest, State Property, Archives, Debts and Assets of the former Soviet Union, 20 March 1992 4.37

Treaty Establishing Friendly Relations between the United States of America and Hungary, signed in Budapest on 29 August 1921, in USTS, no. 660; in 16 AJIL, 1922 13.58

Treaty of London, 17-30 May 1913, in:

G. FR. De Martens, Nouveau recueil généralde traités, Gr. VII 13.40

Treaty of Peace between Bulgaria and

Turkey, signed at Constantinople on 29 September 1913, between Bulgaria and Turkey 13.50
Treaty of Peace between the Allied and

Associated Powers and Austria;

Protocol, Declaration and Special

Declaration, St. Germain-en-Laye, 10

September 1919, entered into force on

16 July 1920, in UKTS 1919 No. 11

(Cmd. 400) $13.57,13.58,13.61$

Treaty of Peace between the Allied and

Associated Powers and Bulgaria, and

Protocol and Declaration, signed at

Neuilly-sur-Seine on 27 November

1919 $13.50,13.52$

Treaty of Peace between the Allied and

Associated Powers, and Hungary,

Protocol and Declaration (Treaty of

Trianon), in: 6 LNTS, p. 187; UKTS

1920, No. 10 (Cmd. 896) 13.57

Treaty of Peace of Lausanne, signed on 24

July 1923, in: UKTS 1923, No. 16

(Cmd. 1929) UKTS 1996, Third Supp.

List, 96 ........ 1.40, 13.33, 13.37, 13.41, $13.44,13.45$

Treaty on the Establishment of German

Unity, 31 August 1990, (1990) 30

ILM 457 $5.19,5.20$

Versailles Treaty, Paris, signed on 28 June 1919, entered into force on 10 January 1920, in: The Treaties of Peace 1919-23, New York, Carnegie

Endowment for International Peace, 1924 14.49

Vienna Convention on Succession of States in Respect of State Properties, Archives and Debts, in: (1983) 22

ILM . $1.18,1.41,1.49,1.50$, 1.51, 6.53, 6.54, 6.55-6.57, 6.64, 6.72, 6.74, 6.75, 6.91, 6.96, 6.98, 6.124, 6.146, 6.148, 6.149, 6.151, 10.03, 14.19, 14.20, 14.21, 14.22, 14.23, 14.65, 15.06, 15.08, 15.10, $15.12,15.16$ 
Vienna Convention on Succession of States in Respect of Treaties, signed on 23 August 1978 and entered into force on 6 November 1996, 1946 UNTS 3, in: (1978) 17 ILM 1488 $1.05,1.12$ $1.18,1.41,1.49,1.50,1.51,2.03,2.04$, 2.05, 2.06, 2.07, 2.08, 2.10, 3.10, 3.11, $3.12,4.18,4.33,5.02,5.03,5.04,5.05$, 5.07, 5.09, 5.10, 5.11, 5.16, 5.17, 5.18, $5.19,5.21-5.26,5.27-5.33,5.43,5.44$, 5.46, 5,48, 5.55, 5.56, 5.75, 5.76, 5.77, 5.80, 5.81, 5.84, 5.86, 5.88, 5.89, 6.53, $6.54,6.58-6.60,6.64,6.68,6.69,6.72$, $6.74,6.75,6.87,6.88,6.91,6.96,6.98$, $6.99,6.121,6.122,6.123,6.124,6.146$, 6.147, 6.148, 6.149, 6.150, 6.152, $6.153,6.197,7.02,7.03,7.04,7.05$, 7.06, 7.07, 8.02, 9.03, 10.01, 10.03,

\section{Exchanges of notes and letters}

Decree for Ratification of the Agreements, Exchange of Notes, Kosovo-Federal Republic of Germany, Sept. 2, 2011 3.14

Decree for Ratification of the Agreements listed in the Exchange of Notes between the Republic of Kosovo and the United Kingdom $3.14,4.20$

Exchange of Notes between the Government of the Kingdom of the Netherlands and the Government of the Former Yugoslav Republic of Macedonia on bilateral treaty relations, signed 27 June and 11 July 1994, entered into force on 11 July 1994 $3.38,3.39$

Exchange of Notes between the

Government of the Kingdom of the Netherlands of the Government of the Republic of Bosnia and Herzegovina on bilateral treaty relations, signed on 21 September 1995 and 29 February 1996, entered into force on 29

February 1996 $3.41,4.29$
Exchange of Notes between the Government of the Republic of Cyprus and the Government of the Republic of Montenegro on the application of the Agreement between the Republic of Cyprus and Serbia and Montenegro on the Reciprocal Promotion and Protection of Investments, done at Nicosia on 21 July 2005 (Oct. 3 and 15, 2008, entered into force on Nov. 5, 2008), COG S.VII 4036, Nov. 30, 2005 6.41

Exchange of Notes between the Kingdom of the Netherlands and the Republic of Montenegro regarding the continuation of bilateral treaties (Nov. 15, 2006 and Jan. 18, 2007), 51 Tractatenblad Van Het Koninkrij Der Nederlanden (2007), no. I 6.41

Exchange of Letters between the Netherlands and the Czech Republic regarding the continuation of bilateral treaties, 8 and 9 December 1994, in: Tractatenblad Van Het Koninkrij der Nederlanden, Jaargang 1995

Nr. 27 6.11

Exchange of Letters between the Netherlands and the Slovak Republic regarding the continuation of bilateral treaties, 9 December 1994, in: Tractatenblad Van Het Koninkrij der Nederlanden, Jaargang 1995

Nr. 27 6.14

\section{Others}

Canadian Model Foreign Investment Protection and Promotion Agreement (2004) 16.12

Decision by the Council of Heads of State of the Commonwealth of Independent States, 21 December 1991, in (1992) 31 ILM $1.37,3.17$

United States Model Bilateral Investment Treaty (2004) 16.12 
REPORTS OF THE IDI, ILA, ILC, OECD AND UNCTAD

Institut de Droit International, 'La protection diplomatique des individus en droit international. La nationalité des réclamations', Session of Warsaw, September 1965, in (1965) 51-II

Annuaire IDI 16.45

Institut de Droit International, 'State

Succession in Matters of Property and Debts', Session of Vancouver, 2001, in (2000-2001) 69 Annuaire IDI .... 1.18, $6.124,10.03,10.13,14.63$

Institut de Droit International, 'State

Succession in Matters of State

Responsibility', 14th Commission, Rap. Marcelo G. Kohen, Resolution, 28

August 2015 ...... 1.18, 1.50, 1.51, 1.52, 4.32, 6.124, 10.03, 13.55, 13.64, 13.84, $13.85,14.10,14.13,14.15,14.17$, $14.18,14.20,14.30,14.35,14.36$, $14.63,16.47$

Institut de Droit International, 'State

Succession in Matters of State Responsibility', Rap. Marcelo G. Kohen, Final Report, 28 June 2015 $14.04,14.05,14.13,14.30$

International Law Association, 'Conclusions of the Committee on Aspects of the Law on State Succession', Resolution no. $3 / 2008$, adopted at the 73 rd Conference of the International Law Association, held in Rio de Janeiro, Brazil, 17-21 August 2008 2.14 $5.87,5.88,6.28,7.05$

International Law Association, 'Rapport Final sur la Succession en Matière de traités', New Delhi Conference, 2002, Committee on Aspects of the Law of State Succession $3.10,3.19,3.20$ 5.20, 5.88, 7.07, 7.09, 10.06

International Law Association, 'Rapport préliminaire sur la succession d'États en matière de traités', 1996, Helsinki Conference $5.48,5.88$
International Law Association, 'Second

Report of the Committee Non-State

Actors in International Law:

Lawmaking and Participation Rights',

Committee on 'Non State Actors'

(2012) 6.132

International Law Association, 'State

Succession, Report of the Buenos Aires

Conference', 1969 $4.45,5.48$

International Law Association, 'Statement of Principles Applicable to the Formation of General Customary International Law', Final Report of the Committee on the Formation of Customary Law, Conference Report, London (2000) 4.26

International Law Association, 'The

Changing Law of Nationality of Claims, Interim Report', by Francisco Vicuña, Committee on Diplomatic Protection of Persons and Property, (2000) $16.39,16.40,16.45$

International Law Commission, 'Addendum to First Report on Diplomatic Protection, by Mr John R. Dugard, Special Rapporteur', 20 April 2000, UN Doc. A/CN.4/506/Add.1 ... 16.39, 16.46

International Law Commission, Draft

Articles on Diplomatic Protection with Commentaries, text adopted at its 58th session, 2006, (2006) II(2) Yearbook

ILC $16.11,16.46,16.49$

International Law Commission, 'Draft Articles on Succession in Respect of Treaties: General Article submitted by the Special Rapporteur as a possible means of covering the question of lawfulness', A/CN.4/L.184, 12 June 1972, in (1972) II Yearbook ILC .......... 5.03, 5.34-5.38, 5.64, 5.72, 
International Law Commission, 'Fifth

Report on Succession in Respect of

Treaties', by the Special Rapporteur,

Sir Humphrey Waldock, A/CN.4/256 and Adds.1-4, 10 April, 29 May and

8, 16 and 28 June 1972, A/8710/Rev.1,

in (1972) II Yearbook ILC 5.03

International Law Commission, 'First

Report by the Special Rapporteur V.

Mikulka on State Succession and Its

Impact on the Nationality of Natural and Legal Persons', UN A/CN.4/467,

(1995) II(1) Yearbook ILC 16.05 16.10

International Law Commission, 'First

Report on Diplomatic Protection, by

John Dugard', 52nd Sess., UN Doc.

A/CN.4/506, 2000 $16.32,16.39$ 16.40

International Law Commission, 'First

Report on Succession of States and

Governments in Respect of

Treaties', by the Special Rapporteur,

Sir Humphrey Waldock, A/CN.4/202,

15 March 1968, A/7209/Rev.1, in

(1968) II Yearbook ILC ....... 5.03, 5.04

International Law Commission, 'First

Report on Succession of States in

Respect of Rights and Duties

Resulting from Sources other than

Treaties', by Mr. Mohammed Bedjaoui,

Special Rapporteur Topic: Succession

of States in respect of matters other

than treaties, A/CN.4/204 and Corr.1

(French only), in (1968) II Yearbook

ILC 94 ...... 10.08, 13.64, 13.77, 13.79,

$13.80,13.81,13.86$

International Law Commission, 'First

Report on Succession of States in

Respect of Treaties', by the Special

Rapporteur, Sir Francis Vallat,

A/CN.4/278 and Adds.1-6, 19 and 22

April, 8, 24 and 31 May and 10 and

21 June 1974, reproduced in

A/9610/Rev.1, in (1974) II(1)

Yearbook ILC 5.03
International Law Commission, 'Fourth Report on State Responsibility' by Mr.

F.V. Garcia-Amador, Special

Rapporteur, A/CN.4/119, in (1959) II

Yearbook ILC ........ 10.09, 10.10, 12.08

International Law Commission, 'Fourth

Report on State Responsibility of the

Special Rapporteur', Mr Roberto Ago,

24th session of the ILC, 1972, UN

Doc. A/CN.4/264 and Add.1, ILC

Report, A/8710/Rev.1 (A/27/10),

1972, chp. IV(B) [72-73] in: (1972) II

Yearbook ILC 71 14.32

International Law Commission, Fourth

Report on Succession in Respect of

Treaties, prepared by the Special

Rapporteur, Sir Humphrey Waldock,

A/CN.4/249, 24 June 1971,

A/8410/Rev.1, in (1971) II(1)

Yearbook ILC ... 4.03, 4.04, 4.05, 4.28,

4.39, 4.43, 4.44, 4.45, 5.03, 5.55, 5.57,

$5.58,5.59,5.60,5.61,5.69,5.73,7.09$

International Law Commission, 'Guiding

Principles Applicable to Unilateral

Declarations of States Capable of

Creating Legal Obligations With

Commentaries Thereto', in: (2006)

II(2) Yearbook ILC 4.10

International Law Commission, 'Ninth

Report on Succession of States in

Respect of Matters Other Than

Treaties', A/CN.4/30111981/Add.1, in

(1981) II Yearbook ILC 14.21

International Law Commission, 'Report of the International Law Commission on the Work of its 21st Session', 2 June-8 August 1969, Official Records of the General Assembly, 24th Session, Supplement No. 10 (A/7610/Rev.1), A/CN.4/220, in (1969) II Yearbook ILC 228 $5.03,5.40,10.01$

International Law Commission, Report of the International Law Commission on the Work of its 24th session, 2 May-7 July 1972, A/8710/Rev.1, in (1972) II Yearbook ILC ... 4.04, 4.05, 4.28, 5.03, 
International Law Commission, 'Report of the International Law Commission on the Work of its 26th Session', 6 May to 26 July 1974, A/9610/Rev.1, in (1974) II(1) Yearbook ILC .......... 2.07, 4.05, 4.08, 4.17, 4.19, 4.20, 4.21, 4.22, 4.33, 4.39, 5.03, 5.30, 5.37-5.41, 5.44, 5.47, 5.49, 5.51, 5.52, 5.54, 5.63, 5.78, $5.85,6.122,7.09,9.03,9.04,9.06$

International Law Commission, 'Report of the International Law Commission on the Work of its 27th Session', 5 May to 25 July 1975, Draft Articles on State Responsibility, UN Doc. A/10010/Rev.1, in (1975) II Yearbook ILC 14.32

International Law Commission, 'Report of the International Law Commission on the Work of its 53rd Session', 23 April-1 June and 2 July-10 August 2001, ILC Report, A/56/10, 2001 $6.117,14.32,16.46$

International Law Commission, 'Second Report on Identification of Customary International Law', by Michael Wood, Special Rapporteur, ILC, 66th session, Geneva, 5 May-6 June and 7 July-8 August 2014, UN doc. A/CN.4/672 6.132

International Law Commission, 'Second Report on State Succession and its Impact on the Nationality of Natural and Legal Persons', by Mr. Vaclav Mikulka, UN A/CN.4/474, (1996) II(1) Yearbook ILC $16.10,16.13$

International Law Commission, 'Second Report on Succession of States in Respect of Matters Other Than Treaties' by Mr. Mohammed Bedjaoui, Special Rapporteur - Economic and Financial Acquired Rights and State Succession, A/CN.4/216/Rev.1, in

(1969) II Yearbook ILC 10.01, 10.03, 10.04, 10.08, 10.09, 10.10, $10.11,10.12,10.13,10.14,10.16$, 12.04, 12.07, 12.08, 13.01, 13.18,
13.31, 13.65, 13.66, 13.77, 13.80, 13.81, 13.82, 13.83, 13.86, 13.94, $13.95,13.97,14.62$

International Law Commission, 'Second Report on Succession in Respect of Treaties', by Special Rapporteur, Sir Humphrey Waldock, A/CN.4/214 and Adds. 1 and 2, 18 April, 9 June and 22 July 1969, A/8010/Rev.1, in (1969) II

Yearbook $5.03,5.66,5.67$

International Law Commission, 'Seventh Report on Diplomatic Protection' by John Dugard, Special Rapporteur, 58th Session, UN Doc. A/CN.4/567, 7 March 2006 16.31

International Law Commission, 'Third

Report on Identification of Customary International Law', by Michael Wood, Special Rapporteur, 67th session, Geneva, 4 May-5 June and 6 July-7 August 2014, A/CN.4/682 .......... 4.23, 4.26, 4.27, 4.30, 4.41

International Law Commission, 'Third Report on Succession in Respect of Treaties', by Special Rapporteur, Sir Humphrey Waldock, A/CN.4/224 and Add.1, 22 April and 27 May 1970, A/8010/Rev.1, in (1970) II Yearbook ILC 5.03, 5.49, 5.50, 5.68

OECD, 'Dispute Settlement Provisions in International Investment Agreements: A Large Sample Survey', (2012) OECD Working Papers on International Investment 2.09

UNCTAD, 'Investor-State Dispute

Settlement: Review of Developments in 2016', ILA Issue Notes No. 1, 2017 2.09

UNCTAD, 'Selected Recent Developments in IIA Arbitration and Human Rights', IIA Monitor No. 2 (2009) 6.137

\section{UNCTAD, 'State Contracts', UNCTAD}

Series on Issues in International Investment Agreements (2004) $11.01,11.03,11.08$ 


\section{UN DOCUMENTS}

Commentaries to the Draft Articles on

Responsibility of States for

Internationally Wrongful Acts

Adopted by the International Law

Commission at its 53rd Session

(2001), November 2001, Report of the

ILC 6.117, 6.162, 6.193

$11.06,14.09,14.10,16.06$

Declaration of Principles of International

Law Concerning Friendly Relations and Co-operation Among States in Accordance with the Charter of the United Nations, adopted by UN General Assembly Res. 2625 (XXV), of 24 October 1970 $1.50,6.115$

Decree on the Natural Resources of

Namibia, Addendum to the Report of the United Nations Council for Namibia, 29 UN GAOR Supp. 24A, at pp. 27-28, UN Doc.A/9624/add 1(1975), Documents diplomatiques, Conférence de Lausanne (Livre Jaune), Vol. 1 (Ministère des Affaires étrangères, Paris 1923) 6.140

Draft Articles on Nationality of Natural

Persons in Relation to the Succession of States, adopted by the ILC on second reading in 1999, ILC Report, UN Doc. A/54/10, 1999, chp. IV, paras 44 and 45, in (1997) II Yearbook ILC 1.18, 1.49, 1.50, 1.51, 6.124, $10.03,16.04,16.06$

ILC, Draft Articles on the Effects of Armed Conflict on Treaties, with Commentaries, UN Doc. A/66/10, (2011) II Yearbook

ILC $6.153-6.159$

Legal Department of the United Nations, UN Press Release, UN Doc PM/473

(12 August 1947) 9.07
Status of the International Covenants on Human Rights; Succession of States in Respect of International Human Rights Treaties, UN Doc.

E/CN.4/1996/76, 9 January 1996 10.15

Titles and Texts of the Draft Articles on

Responsibility of States for

Internationally Wrongful Acts

Adopted by the Drafting Committee on Second Reading, 26 July 2001, UN

Doc. A/CN.4/L.602/Rev.1 6.117 6.162, 11.02, 14.09, 14.31, 14.32, $14.33,16.06,16.07,16.41$,

UN, 'Interim Report of the Special

Representative of the

Secretary-General of the United

Nations on the Issue of Human Rights and Transnational Corporations and other Business Enterprises', John Ruggie, E/CN.4/2006/97, 22 February 2006 6.137

UN, Letter from the Chairman of the Sixth Committee to the Chairman of the First Committee, 8 October 1947, UN Doc A/C.I/212 in UN Doc A/CN.4/149 9.07

UN, 'The Succession of States in relation to Membership in the United Nations Memorandum prepared by the Secretariat', A/CN.4/149 and Add.1, in (1962) II Yearbook ILC 9.07

UN, Treaty section, UN Office of Legal Affairs, Summary of Practice of the Secretary-General as Depositary of Multilateral Treaties, (1999), UN Doc Srr/LEG/7/Rew 7.05 


\section{DOMESTIC LAW INSTRUMENTS AND DOCUMENTS}

American Law Institute, Restatement of the Law Third, the Foreign Relations Law of the United States (American Law Institute Publ. 1987 vol. I ... 5.80, 7.07,

$$
\text { 13.16, 13.66, 14.26, } 14.61
$$

Constitution of Namibia, adopted by the Constituent Assembly of Namibia on 9 February 1990, entered into force on 21 March 1991, UN Doc.

S/20967/Add.2 ..... 13.89, 13.90, 13.91, 14.08

Constitutional Law No. 4/1993, proclaimed by the Czech Republic's National Council, 15 December 1992 3.11

Decision on Proclamation of Independence of the Republic of Montenegro .... 6.38

Declaration by Hassan Bey, Recueil des Actes de la Conference de Lausanne, Serie I, Vol. 3 (Paris, Imprimerie nationale 1923) 1.40

Déclaration du Conseil Européen concernant l'ancienne Yougoslavie, 28 May 1992, UN. Doc. A/47/234, S/24028, Bull. C.E. 6.1992 1.36

Declaration on the Formation of the Federal Republic of Yugoslavia, joint session of the Yugoslavia Assembly, the National Assembly of the Republic of Serbia and the Assembly of the Republic of Montenegro, 27 April 1992, annexed to UN Doc S/23877 of 5 May 1992 1.36

Declaration of the National Assembly of Serbia, 5 June 2006 6.40

Kosovo, 'Agreements on promotion and protection of investments', Investment Promotion Agency of Kosovo .... 6.103,

6.118

Letter of the interim Chargé d'Affaires at the Permanent Mission of Yugoslavia at the United Nations to the UN Secretary-General, 6 May 1993, UN Doc A/46/915, 7 May 1992 1.36 , 4.12
Letter of Lord Lansdowne, Chief of the British Foreign Office, to the U.S. Ambassador, in: Nielsen (n 239) 197 13.104

Letter of the Minister of Foreign Affairs of the Republic of Slovenia to the UN Secretary-General, 27 May 1992, UN Doc. A/47/234, S/24028, 28 May 1992 1.36

Letter from the President of the United

States to the President of Kosovo, Feb. 18,2008 4.18

Letter of Russia's President Yeltsin to the UN Secretary-General, 24 December 1991, UN Doc 1991/RUSSIA (24

December 1991), Appendix in: (1992)

31 ILM 138 $1.37,3.17$

Letter of 3 June 2006 of the President of the Republic of Serbia to the UN Secretary-General 13.11

Order No. 39, 'The Bangladesh Industrial Development Corporation Order 1972' $15.21,15.25,15.26$

Order 140, 'The Bangladesh Industrial

Development Corporation

(Dissolution) Order 1972', November 15, 1972 $15.23,15.27$

Order of the President of the Russian

Federation of 17 March 2014, No. 147

'On recognition of the Republic of

Crimea', The Collection of Legislation of the Russian Federation, 24 March 2014, No. 12 6.106

Proclamation of the National Council of the Czech Republic to all Parliaments and Nations of the World, 17 December 1992 $3.11,4.08,4.28$

Proclamation of the National Council of the Slovak Republic to Parliaments and

Peoples of the World, 3 December 1992 3.11

Report of the Transvaal Concessions

Commission; see Parl. Pap. South

Africa, 1901 [Cd. 623] 13.99 
Resolution State Council Republic of

Crimea No 1745-6/14 - On the independence of Crimea, 17 March

2014 6.104

The Basic Law of the Hong Kong Special Administrative Region of the People's Republic of China 6.45

The Basic Law of the Macau Special

Administrative Region of the People's Republic of China, adopted Mar. 31, 1993, arts. 136, 138 (effective Dec. 22, 1999) $6.48,6.56,6.57,6.87$
Written Statement of the Russian

Federation, Accordance with

International Law of the Unilateral

Declaration of Independence in Respect of Kosovo, Advisory Opinion

(Apr. 16, 2009) 6.105, 6.112 